\title{
Symbiotic performance of grain and wild herbaceous legumes in the Okavango Delta and Tswapong region of Botswana
}

\author{
N. Bernard ${ }^{1} \cdot$ M. Losologolo ${ }^{1} \cdot$ U. Batlang ${ }^{1} \cdot$ S. Ngwako $^{1}$ • G. N. Mashungwa ${ }^{1}$ \\ N.M. Tselaesele ${ }^{1}$ - F. Pule-Meulenberg ${ }^{1}$ (D)
}

Received: 20 June 2017 / Accepted: 24 September 2017 / Published online: 4 December 2017

(C) The Author(s) 2017. This article is an open access publication

\begin{abstract}
The low inherent soil fertility, especially nitrogen (N) constrains arable agriculture in Botswana. Nitrogen is usually added to soil through inorganic fertilizer application. In this study, biological nitrogen fixation by legumes is explored as an alternative source of $\mathrm{N}$. The objectives of this study were to measure levels of $\mathrm{N}_{2}$ fixation by grain legumes such as cowpea, Bambara groundnut and groundnut in farmers' fields as well as to estimated $\mathrm{N}_{2}$ fixation by indigenous herbaceous legumes growing in the Okavango Delta. Four flowering plants per species were sampled from the panhandle part of the Okavango Delta and Tswapong area. Nitrogen fixation was measured using the ${ }^{15} \mathrm{~N}$ stable isotope natural abundance technique. The $\delta^{15} \mathrm{~N}$ values of indigenous herbaceous legumes indicated that they fixed $\mathrm{N}_{2}(-1.88$ to $+1.35 \%$ ) with the lowest value measured in Chamaecrista absus growing in Ngarange (Okavango Delta). The $\delta^{15} \mathrm{~N}$ values of grain legumes growing on farmers' fields ranging from $-1.2 \%$ to $+3.3 \%$ indicated that they were fixing $\mathrm{N}_{2}$. For grain legumes growing at most farms, $\% \mathrm{Ndfa}$ were above $50 \%$ indicating that they largely depended on symbiotic fixation for their $\mathrm{N}$ nutrition. With optimal planting density, Bambara groundnuts on farmers' fields could potentially fix over $90 \mathrm{~kg} \mathrm{~N} / \mathrm{ha}$ in some parts of Tswapong area and about $60 \mathrm{~kg} \mathrm{~N} / \mathrm{ha}$ in areas around the Okavango Delta. Results from this study have shown that herbaceous indigenous legumes
\end{abstract}

Presented at the 17th African Association of Biological Nitrogen Fixation (AABNF) Biennial Conference, Gaborone, Botswana, 17-21 October 2016

F. Pule-Meulenberg

fpmeulenberg@bca.bw

1 Department of Crop Science and Production, Botswana University of Agriculture and Natural Resources, Private Bag 0027, A1 Sebele Content Farm, Gaborone, Botswana and cultivated legumes play an important role in the cycling of $\mathrm{N}$ in the soil. It has also been shown that biological $\mathrm{N}_{2}$ on farmer's field could potentially supply the much needed $\mathrm{N}$ for the legumes and the subsequent cereal crops if plant densities are optimized with the potential to increase food security and mitigate climate change.

Keywords Biological nitrogen fixation · Legumes · On-farm $\cdot$ Rhizobia $\cdot$ Soil fertility

\section{Introduction}

Apart from low soil moisture, one of the major constraints to increasing arable production in Botswana is the low inherent fertility of soils (Pule-Meulenberg and Batisani 2003). Nitrogen $(\mathrm{N})$ is the most commonly deficient mineral nutrient in soils, often contributing to reduced plant growth and crop yields. It can be supplied to agricultural crops as inorganic fertiliser. However, chemical fertilizers are expensive for the resource poor subsistence farmers, and their production and excessive usage may pollute the environment through greenhouse gas production. Biological $\mathrm{N}_{2}$ fixation involving a symbiotic relationship between some members of Rhizobiaceae ("rhizobia") and the Leguminosae is another source of $\mathrm{N}$ for natural and agricultural ecosystems. This legume-rhizobia symbiotic relationship leads to formation of nodules which are sites for nitrogen fixation, where gaseous atmospheric $\mathrm{N}_{2}$ is converted into ammonia. The $\mathrm{NH}_{3}$ formed is released to the host-plant cells, making it possible for legumes to survive well under low nitrogen soils and provides residual $\mathrm{N}$ to the crops following legume plantation in a crop rotation. As shown by Dakora and Keya (1997), up to $10 \%$ of the fixed nitrogen can be leaked to the non-legume during the growing season under intercropping. 
Legumes that fix $\mathrm{N}_{2}$ include domesticated and wild ones. The amounts of $\mathrm{N}$ fixed by grain, herbaceous and tree/shrub legumes growing in different parts of Africa indicate a great variability among species, as well as between sampling sites and countries for the same species (Table 1; Andrews et al. 2011). Various researchers in Africa estimated symbiotic fixation in grain legumes such as cowpea, Bambara groundnut, soybean and groundnut using various techniques (Dakora 1985; Dakora et al. 1987; Sanginga et al. 2001; Ncube et al. 2007; Pule-Meulenberg et al. 2010). These grain legumes have been found to contribute significant amounts of N-fixed ranging from $47 \mathrm{~kg} \mathrm{~N} / \mathrm{ha}$ by
Table 1 Amount of $\mathrm{N}_{2}$ fixed by different legumes from various countries

\begin{tabular}{|c|c|c|c|}
\hline Legume species & Country & $\mathrm{N}$-fixed $(\mathrm{kg} / \mathrm{ha})$ & Reference \\
\hline \multicolumn{4}{|l|}{ Food legumes } \\
\hline Phaseolus vulgaris & Kenya & $17-57$ & Ssali and Keya (1984) \\
\hline \multirow[t]{3}{*}{ Vigna unguiculata } & Kenya & $24-39$ & Ssali and Keya (1984) \\
\hline & Ghana & 201 & Dakora et al. (1987) \\
\hline & Zimbabwe & $73-79$ & Mapfumo and Giller (2001) \\
\hline \multirow[t]{4}{*}{ Arachis hypogea } & Ghana & $32-134$ & Dakora (1985) \\
\hline & Nigeria & $11-63$ & Sanginga (2003) \\
\hline & Kenya & 8 & Gathumbi et al. (2002) \\
\hline & Zimbabwe & $46-50$ & Chikowo et al. (2003) \\
\hline \multirow[t]{2}{*}{ Glycine $\max$} & Nigeria & 94 & Sanginga et al. (2001) \\
\hline & Zimbabwe & $115-127$ & Ncube et al. (2007) \\
\hline Cajanus cajan & Kenya & 142 & Gathumbi et al. (2002) \\
\hline \multirow[t]{2}{*}{ Vigna subterranea } & Ghana & $115-127$ & Ncube et al. (2007) \\
\hline & Zimbabwe & 142 & Gathumbi et al. (2002) \\
\hline \multicolumn{4}{|l|}{ Herbaceous Legumes } \\
\hline \multirow[t]{2}{*}{ Lablab purpureus } & Nigeria & 215 & Sanginga et al. (2001) \\
\hline & Ivory coast & $7-70$ & Nezomba et al. (2008) \\
\hline Crotalaria palliada & Zimbabwe & 173 & Nezomba et al. (2008) \\
\hline Crotalaria ochroleuca & Zimbabwe & 26 & Nezomba et al. (2008) \\
\hline Crotalaria juncea & Zimbabwe & 58 & Nezomba et al. (2008) \\
\hline Eriosema elliticum & Zimbabwe & 7 & Nezomba et al. (2008) \\
\hline Chamaecrista rotundifolia & Nigeria & 144 & Sanginga (2003) \\
\hline Chamaecrista mimsoides & Zimbabwe & 79 & Nezomba et al. (2008) \\
\hline Indigofera astragalina & Zimbabwe & 1.5 & Nezomba et al. (2008) \\
\hline Indigofera errecta & Zimbabwe & 0.5 & Nezomba et al. (2008) \\
\hline Indigofera astragalina & Zimbabwe & 1.5 & Nezomba et al. (2008) \\
\hline Tephrosia villosa & Ivory coast & $27-119$ & Nezomba et al. (2008) \\
\hline Tephrosia radicans & Zimbabwe & 1.4 & Nezomba et al. (2008) \\
\hline Zornia glabra & Malawi & 16 & Cadisch et al. (1989) \\
\hline \multicolumn{4}{|l|}{ Tree/shrub legumes } \\
\hline \multirow[t]{2}{*}{ Sesbania sesban } & Senegal & $43-102$ & Ndoye and Dreyfus (1988) \\
\hline & Kenya & 52 & Gathumbi et al. (2002) \\
\hline \multirow[t]{2}{*}{ Leucaena leucocephala } & Tanzania & 110 & Högberg and Kvarnström (1982) \\
\hline & Nigeria & 304 & Danso et al. (1992) \\
\hline \multirow[t]{2}{*}{ Senegalia senegal } & Nigeria & $<20$ & Sanginga et al. (2001) \\
\hline & Senegal & 5.25 & Sprent and Parsons (2000) \\
\hline Vachellia tortilis & Senegal & 6.24 & Sprent and Parsons (2000) \\
\hline Faidherbia albida & Nigeria & $<20$ & Sanginga et al. (2001) \\
\hline
\end{tabular}


Bambara groundnut in Zimbabwe (Ncube et al. 2007) to $201 \mathrm{~kg} \mathrm{~N} / \mathrm{ha}$ by cowpea in Ghana (Dakora et al. 1987). All of the above-mentioned studies were done on-station. It is clear that on-farm results are different, for example, Naab et al. (2009) measured 4.1-34.2 kg N/ha in some villages in the Upper West Region of Ghana, while PuleMeulenberg et al. (2010) obtained about $156 \mathrm{~kg} \mathrm{~N} / \mathrm{ha}$ onstation in the same region of Ghana. Whether on-farm or on-station, research data on symbiotic fixation in Botswana is scarce. However, studies have shown that cowpea growing on farmers' fields in various parts of Botswana depended on $\mathrm{N}_{2}$ fixation for their $\mathrm{N}$ nutrition with $\mathrm{Ndfa}$ values ranging from 12.5-91.7\% (Pule-Meulenberg and Dakora 2009). Thus, actual amounts of $\mathrm{N}$ fixed by cowpea on Botswana soils under farm conditions are not known.

Besides grain legumes, many herbaceous and tree legumes also form a symbiotic relationship with rhizobia. Herbaceous plants can be used as green manure, where they add the much needed $\mathrm{N}$ into soil for the benefit of a subsequent cereal crop. Amounts of $\mathrm{N}$ fixed vary according to the legume species. For example, in Zimbabwe, Crotalaria palliada fixed $173 \mathrm{~kg} \mathrm{~N} / \mathrm{ha}$ (Nezomba et al. 2008) while Chamaecrista rotundifolia fixed $144 \mathrm{~kg} \mathrm{~N} / \mathrm{ha}$ (Sanginga 2003). Andrews et al. (2011) collated information on symbiotic fixation traits of legumes in natural ecosystems. Their study has shown that indeed dependence on $\mathrm{N}_{2}$ fixation (\%Ndfa) and the input of $\mathrm{N}$ were very varied among the different ecosystems and plant species. For instance, Pterocarpus lucens in Senegal exhibited \%Ndfa of about $35 \%$ while the $\mathrm{N}$ input into the semi-arid ecosystem of Senegal was 13-29 kg N/ha/year (also see Sylla et al. 2002). Although some parts of Botswana are endowed with indigenous herbaceous legumes, information on whether they fix $\mathrm{N}_{2}$ symbiotically with bacteria as well as their level of dependency on symbiotic fixation for their $\mathrm{N}$ nutrition is not known. Pule-Meulenberg and Dakora (2009) established that some tree legumes of the genus Vachellia (formerly Acacia) depended on symbiotic fixation with Ndfa values ranging from 44 to $94 \%$.

Thus so far, very few studies have measured $\mathrm{N}$ fixed under African farm conditions (Adu-Gyamfi et al. 2007; AdjeiNsiah et al. 2008; Naab et al. 2009; Pule-Meulenberg et al. 2010). Other studies have been done in Australia (Peoples et al. 1995a; Herridge et al. 2005) and other parts of the world under very different conditions to those on African farms. Also, to our knowledge, no study has assessed the level of
$\mathrm{N}_{2}$ fixation on herbaceous wild leguminous flora of Botswana as well as their dependency on symbiotic fixation. Therefore, the objective of this study were to: i) assess levels of $\mathrm{N}_{2}$ fixation on farmers' fields by grain legumes; ii) measure levels of $\mathrm{N}_{2}$ fixation by wild herbaceous legumes and assess their dependency on symbiotic fixation.

\section{Methodology}

\subsection{Description of study sites}

Field surveys were conducted in the Okavango panhandle and Tswapong during summer season of 2014 when both herbaceous wild and cultivated legumes were at the peak of flowering. In the Okavango panhandle, the survey was conducted at Seronga ( $\left.18^{\circ} 5011 \mathrm{~S} ; 22^{\circ} 1806 \mathrm{E}\right)$, Ngarange (18 $2431 \mathrm{~S} ; 220125 \mathrm{E}$ ), and Xakao (18 1817 S; $215316 \mathrm{E}$ ), while in Tswapong, this was conducted in Lekobeng (22 44 $16 \mathrm{~S} ; 271117 \mathrm{E})$ and Mmoo-Kokonye (22 $4550 \mathrm{~S} ; 271202$ E); farming areas for the village of Lecheng. The two regions were selected because of contrasting physiography. The Okavango panhandle was characterized by higher annual rainfall (471-548). Historically, the soils of the Okavango Delta area were formed from Aeolian wind Kalahari deposits while those of Tswapong area have been weathered in situ from the parent rocks. Tswapong, is characterized by lower annual rainfall (362-397), and the main landforms are the Tswapong Hills and their foot slopes (Pars et al. 1995). Consequently the soils in the eastern part such as those in Lekobeng are slightly more fertile with slightly higher $\mathrm{pH}$ value, higher cation exchange capacity (CEC) and $\mathrm{P}$ content compared to Xakao soil which is very sandy, has a lower $\mathrm{pH}$, lower CEC and $\mathrm{P}$ content (Table 2). The $\mathrm{N}$ content of the soil was not determined. However, most parts of Botswana are known to have soils with very low organic matter, and consequently low N (Pule-Meulenberg and Batisani 2003; Pule-Meulenberg and Dakora 2007). The soil texture for the two locations is classified as loamy sand for Lekobeng and as sand for Xakao, both soils having a high sand percentage (Table 2) with low retention of nutrients as implied by the low \%clay.

\subsubsection{Plant sampling and processing}

In the Okavango panhandle, the survey was conducted at Seronga, Ngarange and Xakao. In Tswapong area, plants were

Table 2 Properties of soil samples from different study sites

\begin{tabular}{llllllll}
\hline Location & $\mathrm{pH}\left(\mathrm{CaCl}_{2}\right)$ & $\mathrm{CEC}(\mathrm{Cmol} / \mathrm{kg})$ & $\mathrm{P}(\mathrm{mg} / \mathrm{kg})$ & \%Sand & \%Silt & \%Clay & Soil textural class \\
\hline Tswapong (Lekobeng) & 5.52 & 5.07 & 7.93 & 86.0 & 3.0 & 11.0 & Loamy sand \\
Okavango (Xakao) & 5.06 & 1.55 & 5.13 & 95.0 & 2.0 & 3.0 & Sand \\
\hline
\end{tabular}


sampled from Lekobeng, a farming area near Lecheng village. At each farm, for every crop (for example, cowpea, Bambara groundnut and groundnut), an area of $20 \times 20 \mathrm{~m}$ was demarcated where each grain legume was growing and the number of plants counted to estimate the planting density. At each site, four plants per crop species were randomly selected during flowering and dug out. The four plants were collected in separate paper bags and brought back to the laboratory where the roots were gently washed under a stream of water. Plant shoots were separated from roots and oven dried at $60^{\circ} \mathrm{C}$ for $48 \mathrm{~h}$ and milled to a fine powder $(0.5 \mathrm{~mm}$ mesh).

At both regions, (Okavango Delta and Tswapong), in addition of sampling in farmers' fields, a survey of wild herbaceous legumes was carried out around the locations where grain legumes were sampled. At the Okavango Delta, the wild herbaceous legumes sampled belonged to five tribes of the Subfamily Papilionoideae namely; Crotalarieae, Phaseoleae, Milletieae, Indigofereae and Dalbergieae and one tribe of Caesalpinioideae being Cassieae. Whole plants were sampled during their flowering stage. They were dug out and further treated in the same manner as grain legumes. Plants were identified in the field using books and where there doubts or where they were not in the books, samples were pressed and brought to the Botswana University of Agriculture and Natural Resources (BUAN) Herbarium or the Botswana National Herbarium and Botanic Gardens in Gaborone for identification. Some reference herbaceous plants (non $\mathrm{N}_{2}$ fixing) such as weeds growing in close proximity to the sampled legumes were also sampled to estimate soil $\mathrm{N}$ taken up by the legume.

\subsubsection{Determination of $\delta^{15} N$ and $\% N d f a$}

The natural abudance of ${ }^{15} \mathrm{~N} /{ }^{14} \mathrm{~N}$ and $\% \mathrm{~N}$ of field grain legumes from Xakao in Okavango Delta and Lekobeng in Tswapong, and of herbaceous legumes from the Okavango Delta and reference plants were determined by a Thermo Finnigan Delta Plus XP stable light isotope mass spectrometer (Fixon Instrument SPA, Strada Rivolla, Italy) coupled via a Conflo III device to Thermo1112 Flash elemental analyser. About $2.0 \mathrm{mg}$ of each pulverized sample was weighed into a tin capsule (Elementary Microanalysis LTD, Okehampton, UK) and run against two internal reference plant materials namely Nasturtium $s p$. and Vachellia $s p$. The internal standards had been calibrated against an IAEA standard for N, which is atmospheric air. The isotopic composition of ${ }^{15} \mathrm{~N}$ was measured as the difference in the number of atoms of ${ }^{15} \mathrm{~N}$ to ${ }^{14} \mathrm{~N}$ in atmospheric $\mathrm{N}_{2}$ according to Junk and Svec (1958) and Mariotti (1983) as follows:

$\delta^{15} \mathrm{~N}\left(\% /{ }_{00}\right)=\frac{\left({ }^{15} \mathrm{~N} /{ }^{14} \mathrm{~N}\right) \text { sample }-\left({ }^{15} \mathrm{~N} /{ }^{14} \mathrm{~N}\right) \text { standard }}{\left({ }^{15} \mathrm{~N} /{ }^{14} \mathrm{~N}\right) \text { standard }} * 1000$
The proportion of $\mathrm{N}$ derived from the atmosphere, (\%Ndfa) was calculated according to Shearer and Kohl (1986) as follows:

$\% N d f a=\left[\frac{\left.\left(\delta^{15} \text { Nref }\right)-\delta^{15} \text { Nleg }\right)}{\left(\delta^{15} \text { Nref-Bvalue }\right)}\right] \times 100$

Where; $\delta{ }^{15} \mathrm{Nref}$ is the mean ${ }^{15} \mathrm{~N}$ natural abundance of a non$\mathrm{N}_{2}$-fixing reference plants, $\delta^{15} \mathrm{Nleg}$ is the mean ${ }^{15} \mathrm{~N}$ natural abundance of the legume (shoot) and the $\mathrm{B}$ value is the ${ }^{15} \mathrm{~N}$ natural abundance of legume shoots which were totally dependent on biological $\mathrm{N}_{2}$ fixation for their $\mathrm{N}$ nutrition. The $\mathrm{B}$ values used in this study were sought from literature as shown in Tables 3 and 4. For some of the studied legumes, there exist other values in literature. For example, Howieson and Dilworth (2016) have collated B values of some grain and pasture legumes; $-1.08,-0.88$ and $-1.61 \%$ for Crotalaria sp., Arachis hypogea and Vigna unguiculata respectively. Values for Crotalaria sp. and Vigna unguiculata are similar to the ones used in this study while for Arachis hypogea the B value used in our study is substantially different in magnitude from that of Howieson and Dilworth (2016), probably due to genetic differences.

The amount of $\mathrm{N}$-fixed was calculated as Maskey et al. (2001):

$\mathrm{N}-$ fixed $=(N d f a / 100) x$ legume shoot $N$

Table 3 Herbaceous legumes plants found at the Okavango Delta and Tswapong

\begin{tabular}{ll}
\hline Okavango Delta & Tswapong \\
\hline Indigofera flavicans & Zornia glochidiata \\
Indigofera tinctoria & Chamaecrista biensis \\
Chamaecrista biensis & Vigna unguiculata subsp. \\
& dekindtiana \\
Indigofera astragalina & Chamaecrista absus \\
Indigofera daleoides & Tephrosia purpurea \\
Tephrosia purpurea & Rhyncosia totta \\
Tephrosia lupinifolia & \\
Chamaecrista absus & \\
Crotalaria astragalus & \\
Crotalaria sphaerocarpa & \\
Crotalaria pisicarpa & \\
Vigna unguiculata subsp. & \\
dekindtiana & \\
Rhyncosia totta & \\
Zornia glochidiata & \\
\hline
\end{tabular}


Table 4 B values of varied plant species obtained from literature

\begin{tabular}{lll}
\hline Plant & B value (\%o) & Reference \\
\hline Arachis hypogea & -1.4 & Okito et al. (2004) \\
Indigofera sp & -1.5 & Okito et al. (2004) \\
Chamaecrista absus & -1.7 & de Freitas et al. (2012) \\
Crotalaria sp & -1.1 & Gathumbi et al. (2002) \\
Vigna subterranea & -1.4 & Nyemba and Dakora (2010) \\
Vigna unguiculata subsp & -1.7 & Okito et al. (2004) \\
Vigna unguiculata & -1.8 & Pule-Meulenberg and Dakora (2009) \\
Tephrosia purpurea & -2.0 & Raddad et al. (2005) \\
\hline
\end{tabular}

\subsubsection{Statistical analysis}

Statistical analyses were carried out with the Statistical Analysis Software (SAS 9.4) (SAS Institute, Carey, NC). Data on $\delta{ }^{15} \mathrm{~N}, \% \mathrm{Ndfa}, \mathrm{N}$-fixed and $\mathrm{N}$ content were subjected to analysis of variance (ANOVA) after testing for normality. Where means were statistically different they were separated using the Fisher's Least Significant Difference (LSD) method at $5 \%$ significant level.

\section{Results}

\subsection{Mean $\delta^{15} \mathrm{~N}$ values of reference plants}

In addition to herbaceous legume species, non $\mathrm{N}_{2}$ fixing plant species were also sampled as reference plants for the calculation of \% Ndfa using natural abundance technique. These included Ocimum americanum, Panicum sp., an unknown grass species, Erlangea musera, Cassia italica, Termnalia sericea and Senna obtusfolia (Table 5). Mean $\delta^{15} \mathrm{~N}$ values of reference plants ranged from $4.02-5.99 \%$.

\subsection{Occurrence of herbaceous of legumes in the two study sites}

Table 3 presents the results of the legume survey that was undertaken in the Okavango Delta and the Tswapong region.

Table 5 Reference plants and their $\delta^{15} \mathrm{~N}$ $(\% o)$ values

\begin{tabular}{ll}
\hline Plant & $\delta^{15} \mathrm{~N}(\% \mathrm{o})$ \\
\hline Ocimum americunum & 5.99 \\
Panicum sp & 5.39 \\
Unknown grass species & 5.47 \\
Erlangea musera & 4.02 \\
Cassia italica & 4.79 \\
Terminalia sericea & 4.05 \\
Senna obtusfolia & 4.64 \\
\hline
\end{tabular}

In both cases the survey was conducted at four locations. Table 3 shows that more herbaceous legume plant species were found in the higher rainfall Okavango Delta compared to Tswapong area. Further, the two sites appear to have different soil chemical properties, with Tswapong presenting higher $\mathrm{pH}, \mathrm{CEC}$ and phosphorus (Table 2).

\subsection{A comparison of plant growth, $\delta{ }^{15} \mathrm{~N}$ values, $\% \mathrm{Ndfa}$ and $\mathrm{N}$-fixed of grain legumes in farmers' fields in Tswapong and Okavango Delta}

At flowering, there were significant differences in the dry matter of grain legumes growing at the various sites where sampling was done (Table 6). There were no differences in the dry matter accumulated by groundnuts growing in Lekobeng (L), Xakao (Ngando) (XN) and Xakao (Motenya) (XM). Regarding Bambara groundnut, plants growing in $\mathrm{XN}$ were significantly smaller than those grown in Lekobeng and $\mathrm{XM}$. The symbiotic performance of the grain legumes differed significantly among sites at the Okavango Delta and Tswapong area (Table 6). Bambara groundnut growing in Lekobeng exhibited the lowest $\delta^{15} \mathrm{~N}$ value, followed by groundnut from Xakao. In fact, groundnut had the lowest overall $\delta^{15} \mathrm{~N}$ value irrespective of sampling site. For example at Ngando's farm in Xakao, at Motenya's farm in Xakao and in Lekobeng, $\delta^{15} \mathrm{~N}$ values of groundnuts were $0.0,0.5$ and 0.5 $\%$ respectively. It is noteworthy that Bambara groundnut showed the most enriched $\delta^{15} \mathrm{~N}$ values in Okavango Delta region regardless of the farm where they were growing (Table 6). Interestingly, the most depleted value of $\delta^{15} \mathrm{~N}$ was measured in Bambara groundnut $(-1.2 \%$ ) in Lekobeng. Cowpea was only sampled from Okavango in Xakao at Ngando farm and its $\delta{ }^{15} \mathrm{~N}$ value was not significantly different from that of Bambara groundnut growing in the same farm (Table 6).

All the grain legumes sampled were dependent on symbiotic fixation for their $\mathrm{N}$ nutrition. For instance, because Bambara groundnut growing in Lekobeng had the most depleted $\delta{ }^{15} \mathrm{~N}$ value and it was the most highly dependent on $\mathrm{N}_{2}$ fixation with an $\mathrm{Ndfa}$ of $96.4 \%$. Interestingly, of all the 
sampled grain legumes, the least dependent on $\mathrm{N}_{2}$ fixation was also Bambara groundnuts in Xakao at Motenya farm with Ndfa of $28.8 \%$. Data revealed that regardless of sampling site, groundnut generally depended on symbiotic fixation for its $\mathrm{N}$ nutrition with Ndfa values greater than $70 \%$.

There were significant differences in amounts of $\mathrm{N}$ fixed among grain legumes grown at various sites (Table 6). Cowpea and Bambara groundnut grown in Xakao at Ngando (XN) farm fixed the least amount of N, 85.9 and $110.6 \mathrm{mg} \mathrm{N} /$ plant respectively while Bambara grown in Xakao at Motenya (XM) farm, groundnut grown at Motenya (XM) farm and groundnut grown in Xakao at Ngando (XN) farm fixed the highest amounts $\mathrm{N}$ of 624.9, 618.0 and $594 \mathrm{mg} \mathrm{N} /$ plant respectively. When translated to hectare basis using the planting density used by farmers, Nfixed amounts for Bambara grown at $\mathrm{XN}$, groundnut grown at $\mathrm{XM}$ and $\mathrm{XN}$ become $1.3,1.1$ and $1.2 \mathrm{~kg} \mathrm{~N} / \mathrm{h}$ respectively. The relationship between shoot biomass of grain legumes is shown in Fig. 2; it shows that $\mathrm{N}$-fixed amounts increased with increasing biomass.

\subsection{A comparison of plant growth, $\delta{ }^{15} \mathrm{~N}$ values, $\% \mathrm{Ndfa}$ and $\mathrm{N}$-fixed of wild indigenous herbaceous legumes from sites at Okavango Delta}

Because the various legumes were different and therefore had varying growth patterns, there were significant differences in their shoot dry matter at flowering stage (Table 7). There were significant differences in the symbiotic efficacy of the herbaceous legumes at the various sites of the Okavango Delta. Most legumes exhibited considerably depleted values of $\delta^{15} \mathrm{~N}$ as shown by mostly negative figures. Plant species from Ngarange exhibited the most depleted values of $\delta^{15} \mathrm{~N}(\%)$ while plant species from Xakao were comparatively enriched (Table 7). Consequently, the legumes showed a high dependency on symbiotic fixation, values ranging between $57.5 \%$ by Indigofera flavicans sampled from Xakao to $100 \%$ by Chamaecrista absus from Ngarange. The $\mathrm{N}$ contents were significantly different among species with Indigofera daeloides from Xakao showing the highest amount of $\mathrm{N}$ per plant and Crotalaria astragalus the least. All the sampled legumes from the Okavango Delta depended on symbiotic $\mathrm{N}$ fixation with \%Ndfa values of more than 50\% (Table 7). Because \% Ndfa were high, amounts of $\mathrm{N}$-fixed (mg/plant) were in some cases very close to the total $\mathrm{N}$ content. For example in Tephrosia sp., the total $\mathrm{N}$ content was $147.8 \mathrm{mg} /$ plant while $\mathrm{N}$-fixed was $143.4 \mathrm{mg} /$ plant (Table 7) indicating a strong dependence of symbiotic fixation. The shoot biomass of wild herbaceous legumes was correlated with the amount of $\mathrm{N}$-fixed per plant $(r=0.8804$; $p=0.000$ ), that is, $\mathrm{N}$-fixed amounts increased with increasing biomass (Figs. 1 and 2). 


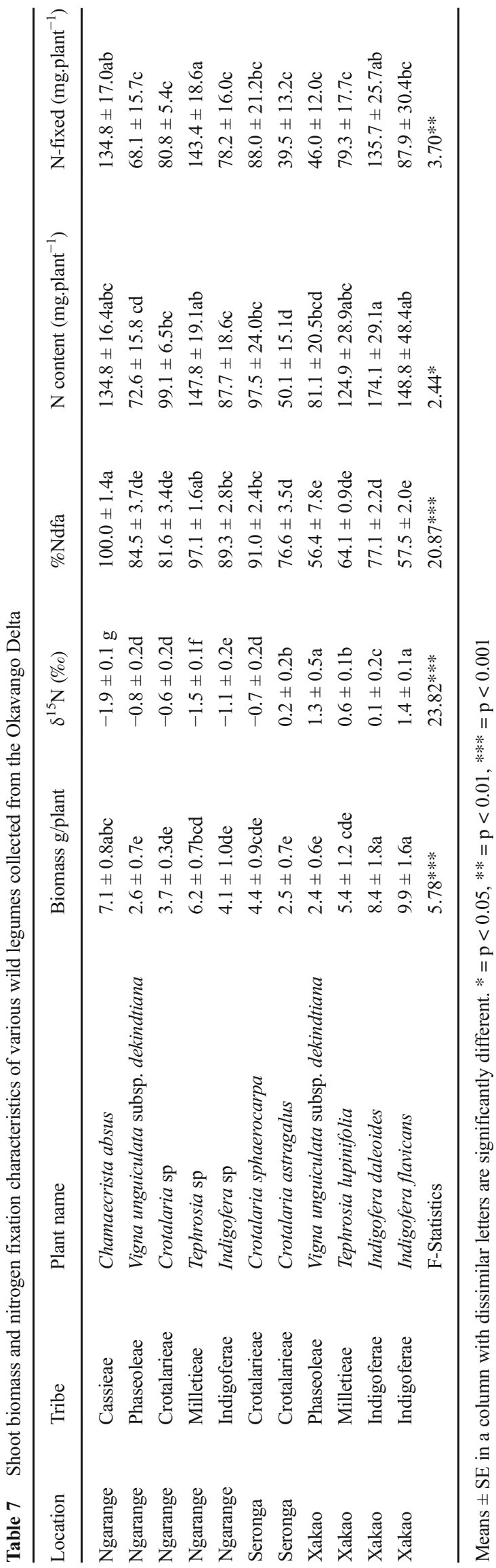

\section{Discussion}

The herbaceous legume survey conducted in some villages of the Okavango Delta and in Tswapong region revealed a larger number of plant species in the Okavango Delta compared to the Tswapong region. While 14 plant species were recorded in the Delta, only seven were found in Tswapong (Table 2), attributed to the higher mean annual rainfall, about $600 \mathrm{~mm}$ in the Okavango, and between 397 and $431 \mathrm{~mm}$ in Tswapong area. Earlier studies showed that the number of putative $\mathrm{N}_{2}$ fixing tree legumes of the genus Vachellia decreased with increasing aridity (Pule-Meulenberg and Dakora 2009), where the wetter Ngwaketse region had more trees than the drier Kgalagadi, suggesting that soil moisture was a major constraint to $\mathrm{N}_{2}$ fixation in tree legumes under prevailing environmental conditions of Botswana.

Nitrogen fixation data in Botswana are very scarce. In other countries, $\mathrm{N}_{2}$ fixation information from experimental stations are freely available (Ncube et al. 2007, Adjei-Nsiah et al. 2008, Peoples et al. 1995, Pule-Meulenberg et al. 2010). In the African continent, on farm $\mathrm{N}_{2}$ fixation data is very limited (Naab et al. 2009; Pule-Meulenberg and Dakora 2009). But, without studies on levels of symbiotic fixation under farm conditions, it is not possible to optimize the contribution of nitrogen by grain legumes on African soils. In this study, symbiotic traits of grain legumes were measured on plants grown on farmers' fields in the Okavango Delta in the northern part of Botswana and in Tswapong area in the east using the ${ }^{15} \mathrm{~N}$ natural abundance technique. Results showed that for some grain legumes (e.g. groundnuts), $\mathrm{N}_{2}$ fixation varied among villages and between the two regions (Table 6). Values of $\delta^{15} \mathrm{~N}$ also showed that Bambara groundnut fixed $\mathrm{N}_{2}$ and that the highest fixation among all legumes was measured in Lekobeng in the Tswapong region. However, despite the low $\delta^{15} \mathrm{~N}$ values exhibited by grain legumes, and the high dependence on symbiotic fixation, amounts of $\mathrm{N}$-fixed on farmers' fields were very low due to low planting densities (Table 6). These low $\mathrm{N}$-fixed figures ( 0.2 to $1.3 \mathrm{~kg} \mathrm{~N} / \mathrm{ha}$ ) are comparable to those measured by Naab et al. (2009) in the Upper West region of Ghana where their lowest $\mathrm{N}$-fixed was $7.4 \mathrm{~kg} \mathrm{~N} / \mathrm{ha}$, despite a low $\delta^{15} \mathrm{~N}$ value of $0.85 \%$ also attributed to a suboptimal planting density. Recalculating $\mathrm{N}$-fixed using optimal densities of 150,000 plants/ha for cowpea, 100,000 plant/ha for groundnut and 15000 plant/ha for Bambara groundnut led to potentially much higher values of $\mathrm{N}$-fixed of $12.9 \mathrm{~kg} \mathrm{~N} / \mathrm{ha}$ for cowpea, $40.8-61.8 \mathrm{~kg} \mathrm{~N} / \mathrm{ha}$ for groundnut and $16.6-93.7 \mathrm{~kg} \mathrm{~N} / \mathrm{ha}$ for Bambara groundnut.

In addition to the sampling of grain legumes from farmers' fields, wild herbaceous legumes were sampled from the Okavango Delta. A comparison of the symbiotic performance of the herbaceous legumes growing in the panhandle part of the Okavango Delta revealed that all the legumes depended on $\mathrm{N}_{2}$ fixation for their $\mathrm{N}$ nutrition (Tables 6 and 7). In a 
Fig. 1 The relationship between shoot biomass and amount of $\mathrm{N}_{2}$ fixed by grain legumes

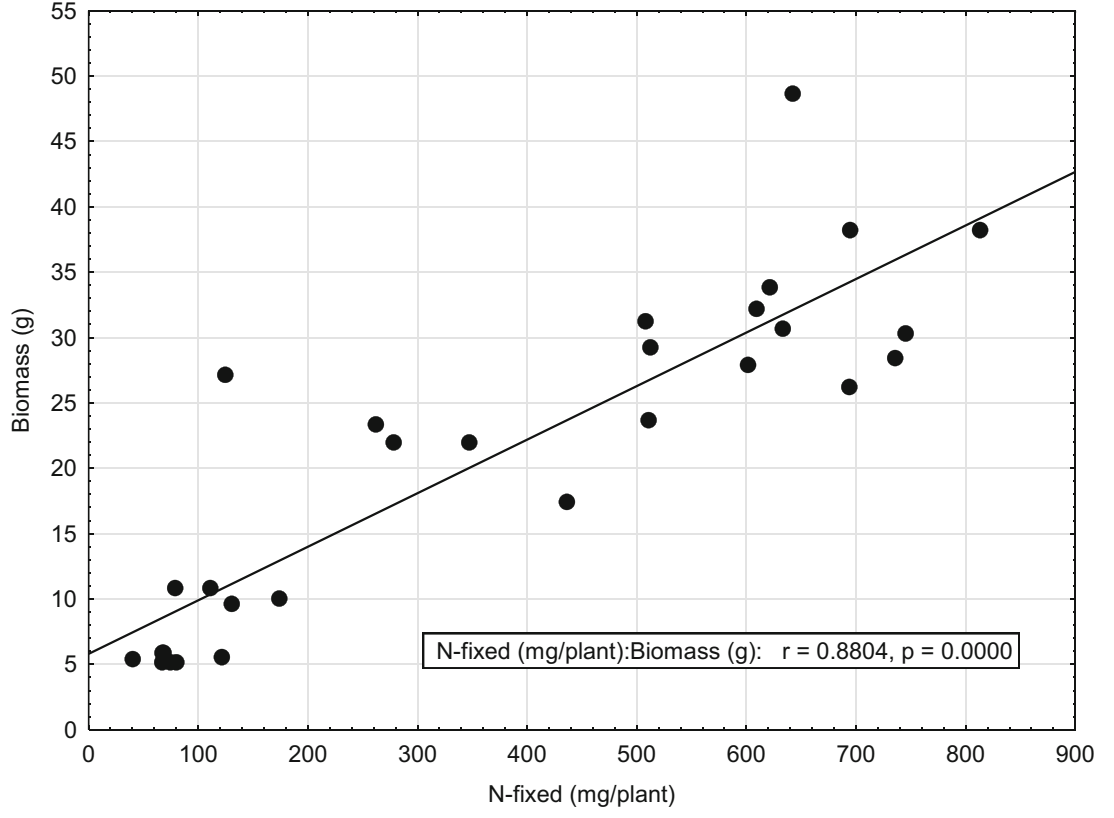

study that investigated ${ }^{15} \mathrm{~N}$ signatures of nodulated legumes in the Cerrado and neighbouring regions of Brazil, Sprent et al. (1996) observed that species of Chamaecrista exhibited $\delta^{15} \mathrm{~N}$ values that indicated that they were fixing atmospheric $\mathrm{N}_{2}$. In this study, a herbaceous species of Chamaecrista absus equally fixed $\mathrm{N}_{2}$ with a $\delta^{15} \mathrm{~N}$ value of $-1.9 \%$. All species exhibited depleted $\delta^{15} \mathrm{~N}$ values of less than $5 \%$, indicating that they were fixing $\mathrm{N}_{2}$ from the atmosphere implying that they have a significant role in the nitrogen cycle in that area by adding nitrogen to the ecosystem and using the fixed $\mathrm{N}$ for supporting their growth. Lemaire et al. (2015) isolated $\mathrm{N}_{2}$ fixing symbionts from root nodules of legumes collected from the Core Cape Subregion (CCR) also known as the
Fynbos area of the Western Cape region of South Africa. There are some commonalities between Lemaire et al. (2015) and the current study in that their legumes belonged to similar tribes namely Crotalarieae, Phaseoleae, Milletieae, Indigofereae and Dalbergieae. Although they did not measure $\mathrm{N}_{2}$ fixation in those plants, they did establish that they were nodulated and formed symbiotic fixation. Data on associated microsymbionts are not presented in this study.

The variation in $\mathrm{N}_{2}$ fixation by both wild herbaceous and field legumes collected from various locations can be attributed to the differences in competitive capability and effectiveness of the indigenous rhizobial population at each location as supported by Martins et al. (2003), that under different soils
Fig. 2 The relationship between plant biomass and amount of $\mathrm{N}_{2}$ fixed by wild legumes

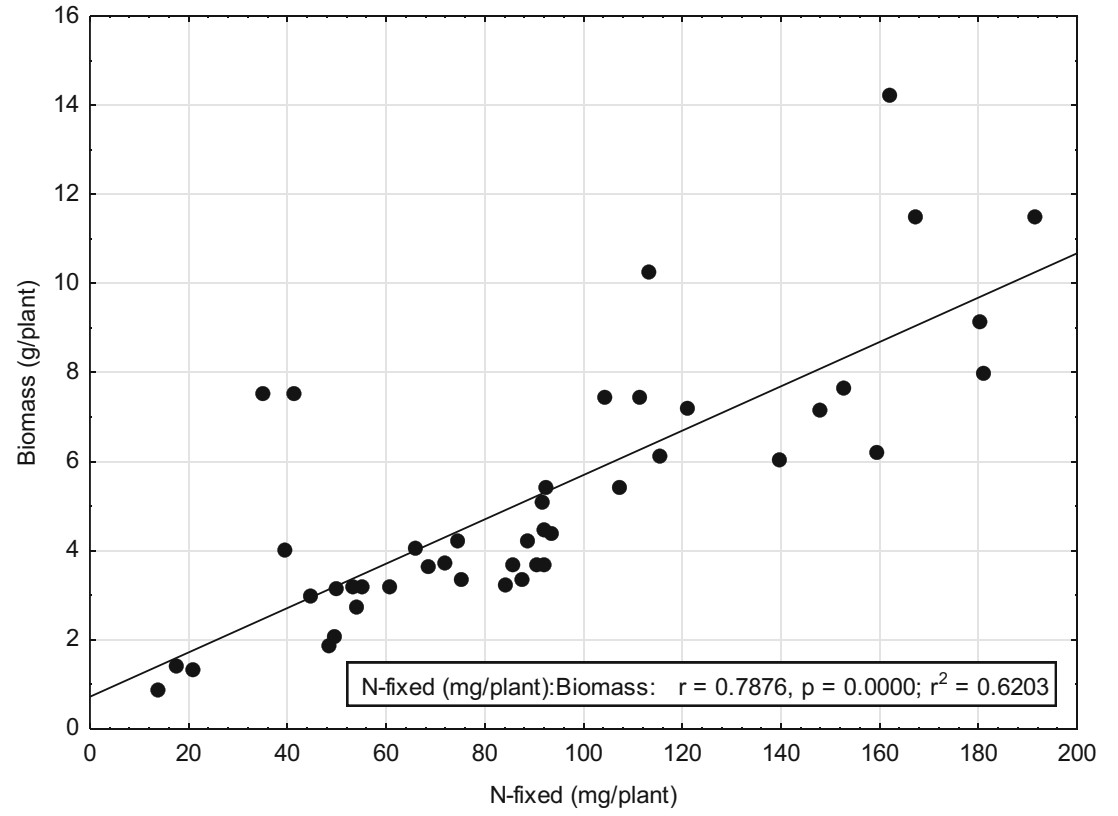


the rhizobial population differs in species composition and symbiotic effectiveness. Also, supporting studies by Mapfumo and Giller (2001) observed that differences in N fixation were mainly due to variability in soil physical, biological and chemical properties for both rhizobia and plants, environmental conditions, cropping history and the management practices together with adaptability of the symbiotic partners to environmental conditions.

In general, when compared to legumes collected from farmer's fields, wild herbaceous legumes had higher \% Ndfa, for example, Chamaecrista absus from Ngarange totally depended on symbiotic fixation for its $\mathrm{N}$ nutrition (Table 7). Higher \% Ndfa shows that the legumes derived majority of $\mathrm{N}$ from fixing atmospheric nitrogen, indicating that they were growing under $\mathrm{N}$ deficient soils compared to field legumes. Equally higher $\mathrm{N}$ fixation by wild legumes due to low soil $\mathrm{N}$ status could be enhanced by the co-existence of legumes with non-legumes in natural ecosystems. A supporting study by Cramer et al. (2007) concluded that non legumes were beneficial for up taking and utilizing $\mathrm{N}$ in the soil, creating $\mathrm{N}$ deficiency in the soil which sequentially boost legumes to biologically fix nitrogen to their optimal level with the consequent improvement of $\% \mathrm{Ndfa}$. Generally, $\delta^{15} \mathrm{~N}$ of reference plants in this study were rather depleted (Table 5). A study by Spriggs et al. (2003) has shown that one of the reasons for low $\delta^{15} \mathrm{~N}$ of non- $\mathrm{N}_{2}$-fixing plants could be mycorrhization. Apparently mycorrhizal fungi discriminate against the heavier ${ }^{15} \mathrm{~N}$ isotope during transfer of $\mathrm{N}$ from the fungus to the host plant, leaving the host plant with a more depleted in ${ }^{15} \mathrm{~N}$. This implies that dependency on symbiotic fixation could be underestimated, thus $\mathrm{N}$-fixed amounts could be higher than reported.

\section{Conclusion}

In conclusion, grain legumes growing on farmers' fields in the Okavango Delta and the Tswapong region of Botswana varied in their levels of $\mathrm{N}_{2}$ fixation. Regarding $\delta^{15} \mathrm{~N}$ signatures, the most depleted value was measured on Bambara groundnut growing in Tswapong region, probably due to low soil $\mathrm{N}$ content. Despite the generally low $\delta^{15} \mathrm{~N}$ of grain legumes, ranging between -1.9 to $1.4 \%$, and high Ndfa values ranging from 28.8 to $96.4 \%$, amounts of $\mathrm{N}$-fixed were very low due to low planting densities. Using optimal planting densities, grain legumes could potentially fix substantial amounts of nitrogen, for example, about $94 \mathrm{~kg} \mathrm{~N} / \mathrm{ha}$ can be fixed by Bambara groundnut in Lekobeng. The wild herbaceous legumes growing in the Okavango Delta equally fixed $\mathrm{N}_{2}$, showing high dependence (56-100\%) on symbiotic fixation. Taken together, this study has shown that symbiotic $\mathrm{N}_{2}$ fixation can play an important role in contributing to the $\mathrm{N}$ economy of crops in farmers' fields. We have also shown that despite a decrease in the diversity of wild herbaceous legumes with increasing aridity, plants are fixing $\mathrm{N}_{2}$ and are dependent on biological nitrogen fixation for their $\mathrm{N}$ nutrition.

Acknowledgements This research was funded under the auspices of the Southern African Science Service Centre for Climate change and Adaptive Land use (SASSCAL Task 316) awarded to Flora-Pule Meulenberg at the Botswana University of Agriculture and Natural Resources (BUAN). Data from this study formed part of an MSc thesis for Nkosilathi Bernard.

Open Access This article is distributed under the terms of the Creative Commons Attribution 4.0 International License (http:// creativecommons.org/licenses/by/4.0/), which permits unrestricted use, distribution, and reproduction in any medium, provided you give appropriate credit to the original author(s) and the source, provide a link to the Creative Commons license, and indicate if changes were made.

\section{References}

Adjei-Nsiah S, Kuyper TW, Leeuwis C, Abekoe MK, Cobbinah J, SakyiDawson O, Giller KE (2008) Farmers' agronomic and social evaluation of productivity, yield and $\mathrm{N}_{2}$-fixation in different cowpea varieties and their subsequent residual $\mathrm{N}$ effects on a succeeding maize crop. Nutr Cycl Agroecosyst 80(3):199

Adu-Gyamfi JJ, Myaka FA, Sakala WD, Odgaard R, Vesterager JM, Høgh-Jensen H (2007) Biological nitrogen fixation and nitrogen and phosphorus budgets in farmer-managed intercrops of maizepigeonpea in semi-arid southern and eastern Africa. Plant Soil 295:127-136

Andrews M, James EK, Sprent JI, Boddey RM, Gross E, dos Reis Jr FB (2011) Nitrogen fixation in legumes and actinorhizal plants in natural ecosystems: values obtained using ${ }^{15} \mathrm{~N}$ natural abundance. Plant Ecolog Divers 4(2-3):131-140

Cadisch G, Sylvester-Bradley R, Nösberger J (1989) ${ }^{15} \mathrm{~N}$-based estimation of nitrogen fixation by eight tropical foragelegumes at two levels of P: K supply. Field Crop Res 22: 181-194

Chikowo R, Mapfumo P, Nyamugafata P, Nyamadzawo G, Giller KE (2003) Nitrate-N dynamics following improved fallows and maize root development in a Zimbabwean sandy clay loam. Agrofor Syst 59:187-195

Cramer MD, Chimphango SB, Van Cauter A, Waldram MS, Bond WJ (2007) Grass competition induces $\mathrm{N}_{2}$ fixation in some species of African Acacia. J Ecol 95:1123-1133

Dakora FD (1985) Nodulation and nitrogen fixation by groundnut in amended and unamended field soil in Ghana. In Biological nitrogen fixation in Africa: proc. of the First Conference of the African Association for Biological Nitrogen Fixation (AABNF) held in Nairobi, Kenya, 23 to 27 July 1984/ed. H. Ssali; SO Keya. Nairobi, Kenya: Nairobi Rhizobium MIRCEN, Department of Soil Science, University of Nairobi

Dakora FD, Keya SO (1997) Contribution of legume nitrogen fixation to sustainable agriculture in Sub-Saharan Africa. Soil Biol Biochem 29:809-817

Dakora FD, Aboyinga RA, Mahama Y, Apaseku J (1987) Assessment of $\mathrm{N}_{2}$ fixation in groundnut (Arachis hypogaea L.) and cowpea (Vigna unguiculata $\mathrm{L}$. Walp) and their relative $\mathrm{N}$ contribution to a succeeding maize crop in Northern Ghana. World J Microbiol Biotechnol 3(4):389-399

Danso SKA, Bowen GD, Sanginga N (1992) Biological nitrogen fixation in trees and agro-ecosystems. Plant Soil 141:177-196 
de Freitas ADS, de Sampaio EVSB, da Silva BLR, de Almeida Cortez JS, Menezes RSC (2012) How much nitrogen is fixed by biological symbiosis in tropical dry forests? 2. Herbs. Nutr Cycl Agroecosyst 94:181-192

Gathumbi SM, Cadisch G, Giller KE (2002) ${ }^{15} \mathrm{~N}$ Natural abundance as a tool for assessing $\mathrm{N}_{2}$ fixation of herbaceous, shrub and tree legumes in improved fallows. Soil Biol Biochem 34:1059-1071

Herridge DF, Robertson MJ, Cocks B, Peoples MB, Holland JF, Heuke L (2005) Low nodulation and nitrogen fixation of mungbean reduce biomass and grain yields. Anim Prod Sci 45:269-277

Högberg P, Kvarnström M (1982) Nitrogen fixation by the woody legume Leucaena leucocephala in Tanzania. Plant Soil 66:21-28

Howieson JG, Dilworth MJ (2016) Working with rhizobia. Australian Centre for International Agricultural Research (ACIAR), Canberra, pp 307

Junk G, Svec HJ (1958) The absolute abundance of the nitrogen isotopes in the atmosphere and compressed gas from various sources. Geochim Cosmochim Acta 14:234-243

Lemaire B, Dlodlo O, Chimphango S, Stirton C, Schrire B, Boatwright S, Honnay O, Smets E, Sprent J, James E, Muasya M (2015) Symbiotic diversity, specificity and distribution of rhizobia in native legumes of the Core Cape Subregion (South Africa). FEMS Microbiol Ecol 91:2-17

Mapfumo P, Giller KE (2001) Soil fertility management strategies and practices by smallholder farmers in semi-arid areas of Zimbabwe. Int Syst Agric Sci Technol 53:20-29

Mariotti A (1983) Atmospheric nitrogen is a reliable standard for natural ${ }^{15} \mathrm{~N}$ abundance measurements. Nature 303:685-687

Martins LM, Xavier GR, Rangel FW, Ribeiro JR, Neves MC, Morgado LB, Rumjanek NG (2003) Contribution of biological nitrogen fixation to cowpea: a strategy for improving grain yield in the semi-arid region of Brazil. Biol Fertil Soils 38:333-339

Maskey SL, Bhattarai S, Peoples MB, Herridge DF (2001) On-farm measurements of nitrogen fixation by winter and summer legumes in the Hill and Terai regions of Nepal. Field Crop Res 70:209-221

Naab JB, Chimphango SM, Dakora FD (2009) $\mathrm{N}_{2}$ fixation in cowpea plants grown in farmers' fields in the Upper West Region of Ghana, measured using ${ }^{15} \mathrm{~N}$ natural abundance. Symbiosis 48:37-46

Ncube B, Twomlow SJ, Van Wijk MT, Dimes JP, Giller KE (2007) Productivity and residual benefits of grain legumes to sorghum under semi-arid conditions in southwestern Zimbabwe. Plant Soil 299: $1-15$

Ndoye I, Dreyfus B (1988) $\mathrm{N}_{2}$ fixation by Sesbania rostrata and Sesbania sesban estimated using ${ }^{15} \mathrm{~N}$ and total $\mathrm{N}$ difference methods. Soil Biol Biochem 20:209-213

Nezomba H, Tauro TP, Mtambanengwe F, Mapfumo P (2008) Nitrogen fixation and biomass productivity of indigenous legumes for fertility restoration of abandoned soils in smallholder farming systems. South Afr J Plant Soil 25:161-171

Nyemba RC, Dakora FD (2010) Evaluating $\mathrm{N}_{2}$ fixation by food grain legumes in farmers' fields in three agro-ecological zones of Zambia, using ${ }^{15} \mathrm{~N}$ natural abundance. Biol Fertil Soils 46:461-470
Okito A, Alves BJ, Urquiaga S, Boddey RM (2004) Isotopic fractionation during $\mathrm{N}_{2}$ fixation by four tropical legumes. Soil Biol Biochem 36: $1179-1190$

Pars S, Moahi TS, Venema (1995) Proposed agricultural land use plan for Ratholo agricultural extension area-Central Region. FAO/UNDP/ Government of Botswana project BOT/91/001 land use planning for sustainable agricultural development. Field Document 3. 88pp

Peoples MB, Ladha JK, Herridge DF. (1995) Enhancing legume $\mathrm{N}_{2}$ fixation through plant and soil management. In: Management of Biological Nitrogen Fixation for the Development of More Productive and Sustainable Agricultural Systems 1995 (pp. 83101). Springer Netherlands

Pule-Meulenberg F, Batisani NJ (2003) A review of Botswana soil fertility research: Current status and prospects. UNISWA J Agric 12:60-67

Pule-Meulenberg F, Dakora FD (2007) Assessing the biological potential of $\mathrm{N}_{2}$-fixing Leguminosae in Botswana for increased crop yields and commercial exploitation. Afr J Biotechnol 6(4):325-334

Pule-Meulenberg F, Dakora FD (2009) Assessing the symbiotic dependency of grain and tree legumes on $\mathrm{N}_{2}$ fixation for their $\mathrm{N}$ nutrition in five agro-ecological zones of Botswana. Symbiosis 48:68-77

Pule-Meulenberg F, Belane AK, Krasova-Wade T, Dakora FD (2010) Symbiotic functioning and bradyrhizobial biodiversity of cowpea (Vigna unguiculata L. Walp.) in Africa. BMC Microbiol 10(1):89

Raddad AY, Salih AA, El Fadl M, Kaarakka V, Luukkanen O (2005) Symbiotic nitrogen fixation in eight Acacia senegal provenances in dryland clays of the Blue Nile Sudan estimated by the ${ }^{15} \mathrm{~N}$ natural abundance method. Plant Soil 275:261-269

Sanginga N (2003) Role of biological nitrogen fixation in legume based cropping systems; a case study of West Africa farming systems. Plant Soil 252:25-39

Sanginga N, Ade Okogun J, Vanlauwe B, Diels J, Carsky RJ, Dashiell K (2001) Nitrogen contribution of promiscuous soybeans in maizebased cropping systems. Sustaining Soil Fertility in West Africa 58:157-177

Shearer G, Kohl DH (1986) $\mathrm{N}_{2}$-fixation in field settings: estimations based on natural ${ }^{15} \mathrm{~N}$ abundance. Funct Plant Biol 13:699-756

Sprent JI, Parsons R (2000) Nitrogen fixation in legume and non-legume trees. Field Crop Res 65:183-196

Sprent JI, Geoghegan IE, Whitty PW, James EK (1996) Natural abundance of $15 \mathrm{~N}$ and $13 \mathrm{C}$ in nodulated legumes and other plants in the cerrado and neighbouring regions of Brazil. Oecologia 105:440-446

Spriggs AC, Stock WD, Dakora FD (2003) Influence of mycorrhizal associations on foliar $\delta^{15} \mathrm{~N}$ values of legume and non-legume shrubs and trees in the fynbos of South Africa: implications for estimating $\mathrm{N}_{2}$ fixation using the ${ }^{15} \mathrm{~N}$ natural abundance method. Plant Soil 255: 495-502

Ssali S, Keya SO (1984) Nitrogen level and cultivar effects on nodulation, dinitrogen fixation and yield of grain legumes. Cowpea cultivars. East Africa. J Agric For 45:247-254

Sylla SN, Samba RT, Neyra M, Ndoye I, Giraud E, Willems A, de Lajudie P, Dreyfus B (2002) Phenotypic and genotypic diversity of rhizobia nodulating Pterocarpus erinaceus and P. lucens in Senegal. Syst Appl Microbiol 25:572-583 